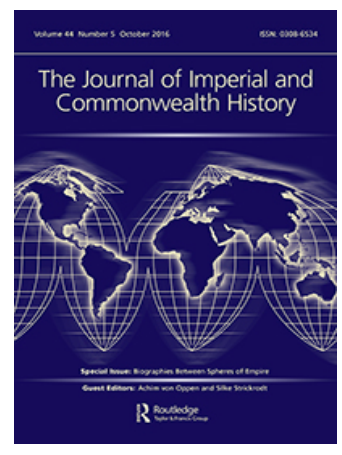

The Journal of Imperial and Commonwealth History

\title{
‘No One Knows What He is Until He is Told': Audience and Personhood in a Colonial African Diary
}

\section{Ruth Watson}

To cite this article: Ruth Watson (2016) 'No One Knows What He is Until He is Told': Audience and Personhood in a Colonial African Diary, The Journal of Imperial and Commonwealth History, 44:5, 815-832, DOI: 10.1080/03086534.2016.1229262

To link to this article: https://doi.org/10.1080/03086534.2016.1229262

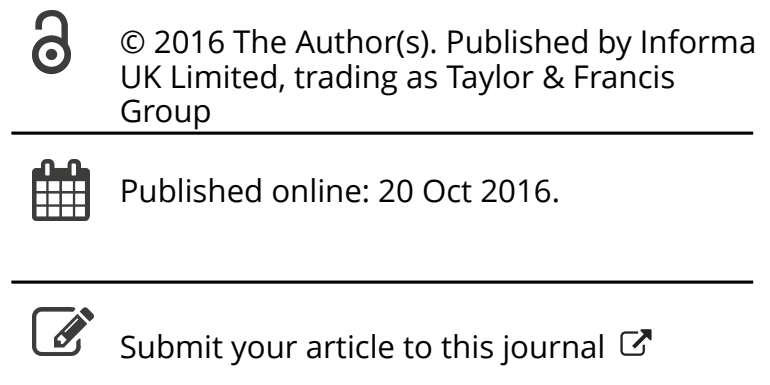

\footnotetext{
Llll Article views: 346
}

\section{Q View related articles $\square$}

View Crossmark data ¿ 


\title{
'No One Knows What He is Until He is Told': Audience and Personhood in a Colonial African Diary
}

\author{
Ruth Watson \\ Clare College, Cambridge, UK
}

\begin{abstract}
This article explores questions of audience and personhood in the diary of Akinpelu Obisesan, a Yoruba man who lived in colonial Nigeria. In particular, it examines how Obisesan wrote between the genres of autobiography and biography so as to generate a sphere for self-fashioning in the colonial context. After introducing Obisesan and exploring briefly the relationship between autobiography, diary writing and the self, I show how Obisesan's diary narrated a deeply relational form of personhood, which he both generated as a writer and consumed as a reader. The article analyses this narrative, exploring how Obisesan constituted various real and imagined audiences for his diary, while simultaneously claiming his privacy and 'archiving himself' into a tin trunk. In the final section of the article, I present a close reading of sections of the 1927 diary, to show how, when writing his diary, Obisesan projected multiple audiences into his text. He used these audiences as a foil for enhancing his own sense of self, thus constituting his personhood and legitimating his precarious social position in colonial society.
\end{abstract}

\section{KEYWORDS}

Autobiography; diaries; Nigeria; Yoruba; literacy; Obisesan

As a genre of personal writing, a diary is often seen as the quintessential primary source for biography. Not only does it enable the detailed reconstruction of an individual life, it also illuminates the lives of people with whom the diary writer interacted. A richly detailed diary sustained over a long period can reveal a cultural and social world, enabling the biographer to write a history of much more than just one person. At the same time, seeing past events through the lens of individual experience makes them all the more tangible and immediate; we see wider patterns of historical change grounded in a single life story. In general, historians tend to value diaries for their content rather than for their form and style, mining them for useful information about particular individuals or for insightful quotations to embellish historical arguments.

CONTACT Ruth Watson $\otimes$ riw21@cam.ac.uk E Clare College, Memorial Court, Queens Road, Cambridge CB3 9AJ, UK

(c) 2016 The Author(s). Published by Informa UK Limited, trading as Taylor \& Francis Group

This is an Open Access article distributed under the terms of the Creative Commons Attribution License (http://creativecommons. org/Licenses/by/4.0/), which permits unrestricted use, distribution, and reproduction in any medium, provided the original work is properly cited. 
However, there is a tension in raiding diaries as historical sources in this way. The diary writer might have conceived their document as private, never intending its contents to be used for public consumption. Alternatively, they could have imagined their daily entries as a form of autobiography, precisely to document their life in their own terms, a purpose somewhat antithetical to their diary being scavenged by a future biographer. Of course, all primary documents are reused and re-interpreted by historians in ways that were often neither anticipated nor intended by their authors. However, the extent to which historical analysis can dismember and then entirely reconstitute a diary narrative makes their interpretation somewhat fraught. Diaries are simultaneously literary and historical texts, as well as therapeutic instruments, while also sometimes being markers of the distinction between private and public life. ${ }^{1}$

Central to using diaries as historical sources, but often ignored, is the question of audience. Who reads diaries and for whom are they written? For the diarist herself or for her family and friends? For a biographer or historian? For an unknown reader of the future? Investigating whom diarists imagined as their audience focuses attention not only on the conscious construction of selfhood, but also on the boundary between autobiography and biography. Critically, autobiographies written by African nationalists played an important role in defining African history as a legitimate academic discipline. ${ }^{2}$ Biographical work in Africa has likewise been tied to the construction of nationalist narratives, but this connection has frequently generated a rather unsatisfactory form of 'heroic history'. Such studies of 'great men' tend to insert the hero's life story within teleological accounts of the rise of political movements, neglecting the relationship between personal and political life and generating a simplistic explanation of the making of selfhood and identity. ${ }^{3}$ Studies of diaries kept by Africans are somewhat rare, although Sol Plaatje's account of the siege of Mafeking during the South African War has gained iconic status. ${ }^{4}$

This article explores questions of audience and personhood in the diary of Akinpelu Obisesan, a Yoruba man who lived in colonial Nigeria. In particular, it examines how Obisesan wrote between the genres of autobiography and biography so as to generate a sphere for self-fashioning in the colonial context. After introducing Obisesan and exploring briefly the relationship between autobiography, diary writing and the self, I show how Obisesan's diary narrated a deeply relational form of personhood, which he both generated as a writer and consumed as a reader. The article analyses this narrative, exploring how Obisesan constituted various real and imagined audiences for his diary, while simultaneously claiming his privacy and 'archiving himself into a tin trunk. In the final section of the article, I present a close reading of sections of the 1927 diary, to show how, when writing his diary, Obisesan projected multiple audiences into his text. He used these audiences as a foil for enhancing his own sense of self, thus constituting his personhood and legitimating his precarious social position in colonial society. 


\section{Akinpelu Obisesan and His Diary}

Akinpelu Obisesan was born in the Yoruba city of Ibadan about 1889 to an Ilesha slave woman called Aruwe. His father, Obisesan Aperin, was an elephant hunter and a chief, who was later appointed to the title of Agbaakin Baale. In this capacity, Aperin was one of 22 chiefs to sign the 1893 Ibadan Agreement, a treaty with the British that marked the beginning of formal colonial rule in the region. Three years on, according to family history, Aperin 'donated' his son Obisesan to the mission station at Aremo. Seven-year-old Obisesan thus became the first member of the Aperin household to obtain a formal education. ${ }^{5}$

Aremo was one of three mission stations established by the Church Missionary Society during the 1850s; it was not far from the Aperin family compound in eastern Ibadan. Once living there, the young Obisesan attended St. Peter's Primary School. He then moved to study in Oyo, before returning to Ibadan in 1905 to work on probation as a clerk in the Resident's Office. The following year he was employed by the Lagos Railway, climbing the ranks to become stationmaster for the town of Ikirun by $1912 .{ }^{6}$ He resigned in 1913 and sometime thereafter became a clerk in an Ikirun produce store, which sold mostly palm kernels. It was during this time that he took up diary keeping, and he purchased his first diary book in 1914.

It seems likely that Obisesan learned to keep a diary at school, since many of his teachers were accustomed to writing journals as part of their missionary work and they possibly passed the habit on to their pupils. ${ }^{7}$ Nevertheless, the earliest entries in the 1914 diary suggest that Obisesan started keeping his journal as part of his career move into the world of colonial commerce. Although his first language was Yoruba, he wrote his diary in English and used it in a businesslike way, recording deliveries of palm kernels to his shop and keeping tabs on the fluctuating price of the commodity. ${ }^{8}$ In this sense, it appears that Obisesan acquired his first diary as an accoutrement to his professional identity as a produce clerk. However, what he wrote in the 1914 volume was much more personal than a clerical record. He constructed a rough family tree, reported on births and deaths and also kept notes on his dreams and visions, as well as sometimes on day-to-day events. ${ }^{9}$ He did this sporadically over a six-year period, so that his 1914 diary volume contains entries dated up to the year 1919, but not written in chronological order. Obisesan was not in the habit of formal diary keeping through this period and preferred to use the 1914 volume as a kind of notebook and aide-memoire.

The style of the diary changed in February 1920, when Obisesan began writing on a daily basis. He had returned to living in Ibadan by this time, and he spent much of his time lobbying colonial officials to support his family's jurisdiction over land that had been claimed by his father in the 1880s. Turned over to cocoa growing, this land had become extremely valuable in the early colonial period, but numerous families contested ownership of it. Obisesan's literacy 
skills were vital for submitting his own family's claims to land title in the colonial courts, and in this context he was appointed as the 'family secretary' ${ }^{10}$ His increased diligence in diary keeping seems to have been related to this development, and was perhaps intended to constitute a record of both 'trespass incidents' and of agreements made with the colonial authorities about land matters. Obisesan also kept account of how much cocoa produce he sold from the family lands and for what price; these details were noted in much the same way that he had recorded details of his transactions when working as a produce clerk in Ikirun. ${ }^{11}$

Once he began writing his diary every day, still always in English, Obisesan turned it into a habit. Across four decades, from 1920 to 1960, he wrote about his work and especially his financial situation, about his intensely felt fears and anxieties, about family tensions and struggles over land, about his intimate relationships with his many wives and children, about his interactions with colonial officials, chiefs and their incessant political intrigues and, occasionally, about events in the wider world. Above all, he wrote about himself, generating a self-reflective and self-referential life narrative of more than 14,000 entries, and an exceptional historical source for colonial Africa. Significantly, the diary is just part of the enormous Obisesan Papers collection, which contains 85 boxes of material, including private correspondence, school reports, newspaper cuttings and government documents.

The collection also contains numerous papers related to the Nigerian cooperative movement, which Obisesan pioneered by establishing farmers' cooperatives for selling and marketing cocoa in western Nigeria from the 1930s onwards. Through this enterprise, Obisesan made his fortune and ultimately established himself in the higher echelons of late colonial society. By the time he died in 1963, Obisesan was a wealthy and well-known public figure, remembered for his leadership of the cooperative movement, as well as for his prominent roles in local and national politics. This status as a member of Nigeria's elite class, however, was in stark contrast to the first few decades of his working life. During this earlier period, especially through the 1920s, his finances were an unmitigated disaster and he struggled perpetually for social and political recognition. As he barely scraped a living as a produce buyer working for various European trading firms, he assiduously recorded his daily thoughts in his diary. Consequently, we have a fascinating account of what it was like to live the life of a marginal gentleman on the fringes of respectable society in colonial Nigeria.

\section{Autobiography, Diaries and the Self}

Obisesan's diary can be viewed as a form of autobiography insofar as, like all diaries, it renders self-realisation as a narrative. However, diaries record a person's life in the moment and do not usually adopt the reflective, distanced 
perspective that has been said to characterise autobiography. ${ }^{12}$ More often, diaries present various messy and occasionally contradictory accounts of diverse life events, and not a single, unified account of an autonomous individual. ${ }^{13}$ Writing about the Indian diarist Amar Singh, who kept a diary continuously for 44 years (filling 90 volumes averaging 800 pages each), Susanne and Lloyd Rudolph observe that 'the autobiographer, like the historian, can interpret and give meanings to acts and experiences which the diarist has neither the motive nor opportunity to interpret'. ${ }^{14}$ In their eyes, 'autobiography, journal and memoir are meant for the public, the diary for the self. ${ }^{15}$ The diary is governed by the logic of its daily entry, they contend, while the autobiography adopts the logic of hindsight:

But the exigencies of daily entry preserve prior understandings of the self and of experience which the retrospective view of autobiography interprets or selectively suppresses ... . Diary writing reveals a person in the making, potential identities, unfulfilled selves, inconsistencies and contradictions, abandoned paths, wrong turns, acts of events that proved embarrassing or shameful. ${ }^{16}$

As we shall see, Obisesan 'made his person' in part by writing his diary between the genres of autobiography and biography, which is most evident in the way he manipulates ideas of audience. Through constructing various types and notions of audience Obisesan generated a sphere that enabled him to mediate colonial boundaries and manage the liminal social spaces in which he found himself. This capacity of the diary to make an aspirational space for self-fashioning is described by the Rudolphs as 'the truth of existentially recorded experience'. ${ }^{17}$

Importantly, despite asserting that a distinction between public and private separates autobiographical and diary writing, the Rudolphs concede that the boundary is blurred. 'There is no purely private self', they claim. Diarists often incorporate a social voice into their self, which 'perches on the diarist's shoulder $^{\text {'18 }}$ as a sometimes obtrusive observer, functioning as what we might term an 'implied reader'. ${ }^{19}$ In short, 'the self constructed in a diary, like the self constructed in an autobiography, is mediated by the author's socialisation'. ${ }^{20}$ In this context we should acknowledge that the Western humanist concept of the autonomous individual self is neither universal nor eternally given; nor is it valid for all time and for all places. It is a product of history and culture. ${ }^{21}$ It is simply unsustainable to suggest that all autobiography is defined by (and also defines) the concept of an autonomous self, and that alternative ideas of self and autobiography are illegitimate.

On the one hand, theorists have in different ways deconstructed the very idea of a unified, autonomous self, suggesting that it is in many ways an illusion, a construct of modern bourgeois ideology. From different vantage points they 'have converged in the idea that the person (in anthropology) or the subject (in critical theory) is split, multiple and unstable'. ${ }^{22}$ On the other hand, an assumed opposition between western individualism and non-western collectivity 
is at best a crude caricature, and at worst a racist essentialism. Many nonwestern societies have ancient literary traditions, notably praise poetry, which ascribe to persons 'a strong sense of self and agency, while also considering the person to be indissolubly meshed into a social, relational world'. ${ }^{23}$ Equally, like all human beings, individuals in Western societies are tied into relationships of reciprocity and mutual obligation. A close relationship might exist between individual identity and writing autobiography, but even an autonomous and atomised individual would surely need to frame his life in words with reference to friends and family and in turn consider how these social relationships had formed and shaped his sense of self over time.

In colonial contexts, contrary to the notion that writing autobiography indicated 'intellectual colonising', even if colonial subjects adopted or appropriated new forms of self-understanding in their autobiographies, the genre actually enabled alternative concepts of the self to be retained, realised and reconfigured. Confessional autobiographies, for example, used self-conscious and deliberate self-examination as a didactic medium. Through this means, Gandhi sought to teach his compatriots about the moral life that he believed should be the foundation for a new India. ${ }^{24}$ In northern Nigeria, the diary of Hamman Yaji reveals how one local ruler experienced and responded to the colonial presence through the years 1912 to 1927. One of its striking features is how meticulously gifts and obligations were recorded, so much so that it was impossible to index the word 'gift' as it appeared on almost every page. ${ }^{25}$ This is a good demonstration of individual and collective identities mutually constituting each other - gifts recognised Hamman Yaji's individual status but also emphasised the importance of reciprocity and mutual collective recognition. Further, the content of the diary changed with the 'gradual tightening of the colonial epistolary net'. ${ }^{26}$ As the British took firmer control of his lands after 1920, he wrote less of his slaving expeditions and more about letters he received from colonial officials, thus inserting himself into a wider colonial network. ${ }^{27}$ Thus writing autobiography does not necessarily indicate taking on ideas of Western individualism, but might instead indicate experimenting with, challenging or even subverting the whole concept. African autobiographies also often combined political and religious discourse with the telling of a life story, particularly in Kenya, where autobiography was the most widely practiced literary genre in the colonial period. ${ }^{28}$

Perhaps more useful than the restrictive notion of a contained, individual self is the more flexible idea of personhood. Persons are not given, but made; thus personhood can be seen as an emergent historical process rather than an essential and eternal analytical category. ${ }^{29}$ The concept also allows for the fact that individual and collective identities need not be mutually exclusive and might well jointly constitute each other. Importantly, texts have a crucial role in conceptualising personhood, because, as Barber argues, 'texts are central to understanding what it is to be a person, in every culture' ${ }^{30}$ Texts help to constitute 
personhood, and also to shed light on how personhood is constituted, both individually and relationally. Indeed, some texts break down the distinction between individual and collective worlds altogether, by addressing persons as distinct individuals while simultaneously working to expand, evoke, intensify and recognise social being. ${ }^{31}$

Within this broad conceptual framework, texts such as Obisesan's diary can be analysed as autobiographical texts that are both documents of and modes of making personhood. As a self-narrative that relates to and is engaged with the diarist's social world, a diary locates the person within a network of social relationships. A diary also locates and gives meaning to an individual's internal feelings of tension or disequilibrium, illuminating the fragmented and multidimensional experience of personhood. The textual structure of any diary is necessarily complex in shape and pattern and takes varied forms, such as disjointed narrative, the use of various assumed and multiple voices, or even a set of blank pages. ${ }^{32}$ What is excluded from a diary is also revealing; while some diarists do not privilege extraordinary over ordinary events, others do. It is also quite common for diarists to write 'nothing happened' as their daily report. ${ }^{33}$ Obisesan, for example, uses the phrase 'nothing of importance' in his diary on a fairly regular basis. ${ }^{34}$ Rather than interpreting this comment at face value, the task of the historian is to wonder what 'nothing' actually means in terms of a person's understanding of their life.

\section{Personhood, Privacy and Tin-Trunk Literacy}

On 10 April 1939, Obisesan went to the police to report that one of his daughters, Latundun, had 'absconded' four days previously, 'which action has brought sorrow' he wrote. ${ }^{35}$ Two days later, he informed the local District Officer 'of Latundun's missing from home' and mentioned in his diary entry that 'a stream of sympathisers came to see me. ${ }^{36}$ Following a false alarm that Latundun had been seen walking in the vicinity of a nearby village, at the end of the week, the police found her in the railway town of Minna, far away in Northern Nigeria. Obisesan made arrangements for the girl to be brought home and then went to spend the weekend at Akanran, one of his family farms on the outskirts of Ibadan. ${ }^{37}$ 'Between yesterday \& today', he wrote on 15 April, 'about 50 men \& women came to express sympathy for the missing of Latundun'. ${ }^{38}$ The next day, this continued: 'Stream of sympathisers continue to pay me visit $\&$ to me this is an eye-opener that all Aperin's people truly love and esteem me; but some do show sympathy out of respect. No one knows what he is until he is told'. ${ }^{39}$

In his account, Obisesan gives no indication of what might have prompted his daughter to run away or indeed how she managed to travel as far as Minna. His focus is instead very self-absorbed, emphasising the manner in which his father's family attended to him and his emotional needs. He seems narcissistic when recounting that family members 'truly love and esteem me'; insecure when he writes that 'no one knows what he is until he is told'. But rather than narcissism 
or insecurity, this episode is one of many similarly described incidents, which reveal how deeply relational Obisesan's sense of self was. For him, personhood was constituted through the social gaze and approbation of others. In this context, a central function and purpose of his diary was to record accounts of such approbation, because these narratives told him not only what or who he was, but also who he might become.

We can understand why this was so if we consider that when Obisesan began writing his diary on a daily basis in 1920, his experiences of social recognition were few and far between. He was a marginal figure in the social and cultural life of colonial Ibadan, and he depended on the patronage of others for his economic and social survival. Adeboye has suggested that the keeping of personal diaries 'characterized the life of the educated elite' in southern Nigeria at the time, but her assertion as applied to Obisesan is somewhat misleading. ${ }^{40}$ The self-image of being an educated gentleman was important to him, but his diary entries more often expressed his sense of being excluded from this social set. Instead of asserting the fixed identity of belonging to an elite, his diary was far more concerned with managing the experience of liminality and of being on the social margins of elite status. Through describing how, when and why members of his household and the wider Ibadan community respected and honoured him, Obisesan used his diary as a tool of self-realisation. ${ }^{41}$

Obisesan engaged in this process of self-affirmation not only through writing his diary, but also through reading it. He was the primary reader of his text, taking the time to peruse past volumes and then making annotations, editing or adding to his entries. These annotations were often made on entries concerned with how certain individuals responded to him, especially persons he regarded as superior in rank, and thus again we see his relational constitution of personhood. For example, on 24 November 1920, he described how he provided witness testimony in an important land case, expressing satisfaction that Captain Ross, the British Resident, had appreciated his statements. Referring to Ross, Obisesan goes on, 'perhaps he will be induced to regard me as one assisting to bring justice to the door of everyone thank god'. Sometime later, Obisesan re-read this entry and annotated it in a different coloured pen with the word, 'Remarkable'. ${ }^{42}$

Elsewhere, I have explored how Obisesan's diary can be considered as an example of 'tin-trunk literacy', a particular type of colonial literary culture that developed around a group of African readers and writers who emerged as a distinct group in the years between the two World Wars. ${ }^{43}$ Rather than being part of the modernising elite who later became leaders of the post-Second World War nationalist movements, these were literate men and women who hovered on its boundaries. Aspiring intellectuals who actively constituted their own experiences of literacy, their literary interpretations and contributions were part of wider struggles over education, religion, history and morality that were contested through the pages of colonial newspapers and in the debates of local reading clubs. The term 'tin-trunk literacy' arose out of the idea that this group of readers and writers 
kept their literary materials - books, magazines, notebooks, diaries and newspapers - in tin trunks. ${ }^{44}$ This was certainly the case for Obisesan, whose diaries were kept under lock and key in tin trunks under his bed. ${ }^{45}$

Such careful preservation raises the issue of whether Obisesan's diary was a private document. Referring generally to the diaries of the 'Ibadan educated elite', Adeboye declares: 'In terms of composition and content, these diaries were meant as strictly private records, not written for any audience' ${ }^{46}$ Certainly, it is clear that the daily ritual of keeping a diary was a way that Obisesan claimed privacy for himself. In an interview decades later, his son Lapade recalled that when Obisesan sat down to write a diary entry, everyone in the household knew that he should be left alone and undisturbed. ${ }^{47}$ The activity of diary writing thus actually constituted a private space around Obisesan and, for a short while every evening, effectively removed him from the public space of his compound. Furthermore, since Obisesan was also writing about himself, his assertion of individual privacy appears even stronger.

As Barber suggests, 'the idea that writing makes possible new forms of selfapprehension and self-fashioning is a seductive one'. ${ }^{48}$ One can write down thoughts, read them over, and then reflect upon, erase and correct the text, thus monitoring and to some extent remake one's sense of self. 'A person comes to a new consciousness of self through selecting and shaping thoughts in the process of giving them external form', she proposes. ${ }^{49}$ However, in the case of Obisesan, whether his diary text and the personhood it constituted were 'strictly private' is a complex question. In many ways, the capacity of writing to externalise and create a text that is simultaneously outside of and independent of both writer and reader lends itself to plural and public forms of self-expression and self-consciousness, rather than individual and private experiences. In the personal texts created by obscure aspirants to literacy in colonial Africa, such as men like Akinpelu Obisesan, 'the self was not so much "excised", argues Barber, 'as experimentally projected onto multiple screens' 50

This notion of 'multiple screens' begs questions about the audience for an ostensibly private text such as Obisesan's diary - to whom was he projecting himself and who was watching? Members of his household watched as he wrote privately, but most of them were illiterate. It is unlikely that they would have been able to read his diaries, even had they wanted to, and thus it was quite easy for Obisesan to keep the contents private. All the same, he still banned his literate children from being anywhere near his locked tin trunks. ${ }^{51}$ In this respect, Obisesan was quite unlike Kofi Boakye Yiadom, a Ghanaian schoolteacher 30 years his junior, who declared:

I do loudly read my old diaries to [be heard by] my wife, children, grandchildren and the householders to their amusement, laughter and sorrow, knowing and studying my progress, backwardness or retrogression in life; so that they too may be aware of themselves in their living. ${ }^{52}$ 
By contrast, Obisesan did not use his diary to project himself before an audience. Instead, he used his diary to project, in private, an audience before him. Then, when he read over his diary entries, he became an audience of both himself and of his projected audience, before which he could re-constitute his personhood all over again. Being both the keeper and the audience of his diary, Obisesan thus narrated and made his personhood by simultaneously composing individual and social being. Diary writing enabled him to claim privacy, but this went hand in hand with a socially constituted self-identity that was plural rather than unitary. Obisesan not only projected himself onto multiple screens in his diary, he also projected in a multiplicity of audiences to watch.

\section{Diary Writing and Audiences of Personhood}

Although Obisesan and Yiadom had different conceptions of their diaries' audiences, they both kept their diaries in a special place. Obisesan stored his in locked tin trunks; Yiadom used a glass-fronted cabinet. Miescher describes Yiadom's cabinet, 'full of papers, books, notebooks and old magazines and journals, neatly stacked and protected from the tropical humidity', as a 'shrine to literacy' ${ }^{53}$ Obisesan's tin trunks, on the other hand, could be described as a monument to self-preservation, a legacy of a lifetime's hoarding of precious texts. While his diary can be considered unique in the context of colonial African history, the existence of his personal archive is not an historical accident. Its sheer scope, as well as its particular form - diaries and personal correspondence in addition to official documents - reveals a type of local, do-it-yourself archiving that characterised tin-trunk literacy. ${ }^{54}$

The care with which this personal archive was assembled suggests that Obisesan possibly anticipated a wider audience (beyond himself) for the material in his tin trunks. Like the South African herbalist Louisa Mvemve, who sent hundreds of letters to officials of the Native Affairs Department from 1914 until the early 1930s, or the Nyasaland clerk Kenneth Mdala, who kept up a voluminous correspondence with British officials between the late 1920s and early 1940s, it appears that Obisesan was 'archiving himself. ${ }^{55}$ His papers were eventually archived, of course, which is why they are available to historians today. In 1965, two years after his father's death, Lapade Obisesan gave the carefully tended tin trunks to the University of Ibadan Library. The political scientist George Jenkins facilitated the transfer, later using some of Obisesan's documents for a biography of Adegoke Adelabu, a Yoruba politician who was one of Obisesan's main political opponents from the late 1940s onwards. ${ }^{56}$ This use of Obisesan's archive is somewhat ironic, because although Obisesan admired and envied Adelabu's abilities in the English language, he decried his populist politics. It was almost certainly not Obisesan's intention for his personal papers to illuminate the life of his political rival. ${ }^{57}$ 
All the same, Obisesan probably knew that he could not control how a future reader might use his diary. This is possibly why he was so prescriptive about projecting audiences into his text; he wanted to ensure that his social exchanges were read in the way he experienced them. But more significantly, since he was in any case the main reader of his diary, his many narratives describing how he was received and treated by the various people he encountered in everyday life became multiple screens on which he could view his socially constituted self-identity. By doing this, accompanied by his pre-projected audiences, Obisesan could all at once write, read and imaginatively watch his own life. Through this process, he asserted his precarious social position on the margins of colonial society and claimed self-respect.

To explore fully this process of making personhood, a section of Obisesan's 1927 diary will be analysed here as a case study. In this year, Obisesan was 38 years old and a produce buyer for the trading firm of Miller Brothers, which was a subsidiary of the United Africa Company (UAC). He had been writing his diary every day since February 1920, amid a seemingly never-ending struggle to establish himself as gentleman in colonial Ibadan. On 26 February, he confessed:

Where I am I cannot say. My oft repeated expressions of fear \& misfortune at the end of month like this I am sure would make the reader of this my daily notes in future to pass slighting remarks - but I would ask how could he or she know of the time in which she or he never lived? ${ }^{58}$

Obisesan was at this point suffering one of his recurrent financial crises; earlier in the week he noted that his income had dropped by $£ 150$ in comparison with the previous month. ${ }^{59}$ Matters were made worse by his 'having been involved in many debts', he acknowledged, with one creditor in particular pressing him for payment. ${ }^{60}$ 'That I have \& continued to live in the abode of misfortune $\&$ loss is a fact no one can gainsay', he lamented on 23 February. ${ }^{61}$

His entry three days later is intriguing, however, because he rises above his predicament and attempts to constitute himself as a historical subject, by appealing directly to 'the reader of this my daily notes in future'. Obisesan constructs his present, seen from the anonymous future reader's perspective, as history and the past, hinting hopefully that one day someone might puzzle over his writings. Projecting this person before himself, he seeks respect and understanding for his financial woes, and defends himself from hypothetical criticism by asking rhetorically how an audience of the future could 'know of the time in which she or he never lived?' Once in this imaginary social sphere, Obisesan can reconstitute his self-identity, coping with his feelings of despair and marginality by pleading that his future reader should not judge him as a financial failure.

The strategy seemed to work; on 28 February, a 'signal response made by the customers' enabled Obisesan to earn some money. ${ }^{62}$ 'Customers responded well' he noted again the next day, nonetheless remarking darkly, 'there are still some 
who are being found playing the usual cards' ${ }^{63}$ But it appears Obisesan's selfconfidence was restored, because on 9 March he took the rather dramatic step of buying a car. The entire deal was negotiated via correspondence and Obisesan fully projected his audience with the seller into his entry for the day:

Wrote to Mr Barnes - \& to my gratifying surprise he replied as if he were an African 'Dear Mr Obisesan' he addressed the letter the rarest I ever seen a white done in Ibadan - I sent $£ 5$ deposit to Mr. Barnes for his car which I bargain to purchase for $£ 170 .{ }^{64}$

Extremely gratified that Mr. Barnes communicated 'as if he were an African', Obisesan was filled with pride to receive a letter from a white man addressing him as 'Dear Mr Obisesan'. Here was audience recognition, literally spelled out in writing! Curiously, there is no detail about the car itself, which seems to be little more than a vehicle for Obisesan's projections of grandeur.

Less than a fortnight later, Obisesan's self-doubt returned and he was in a 'state of cogitation about Mr. Barnes's car'. Acknowledging that he had already made a formal commitment, he conceded, 'I have in writing promised to buy without first examining in details the proposed revenue due to me. Here and there I am being faced with financial troubles the origin of which is partly my fault \& mostly the fault of the circumstances under which I live'. ${ }^{65}$ In this case, Obisesan projected an audience with himself. Holding a private internal chat, he absolved himself from full responsibility for his 'financial troubles' and instead blamed his predicament on a combination of fate and foibles. Obisesan commonly invoked 'fate' as an explanation of his situation, as a strategy to avoid confronting the fact that he lived beyond his means. On 5 April, less than a month after he arranged the car purchase, he defaulted on a $£ 100$ payment due to Mr. Barnes. 'Having failed', Obisesan noted, 'I sent him a telegram today'. ${ }^{66}$

The next week, Obisesan had an audience with his boss:

Glory be to God. Mr. Knox after some lively conversation agreed to give me the newly imported car called Chevrolet $-\mathfrak{£ 1 7 5}$ is the cost, half of same to be paid \& the balance by unsettled term of instalments. Thus in this way the arrangement to buy Mr. Barnes' car automatically came to an end \& knowing what breaking of agreement with this kind-hearted gentle Englishman will lead to I wrote \& sent a registered letter to him expressing my profound apology \& offering to forgo the $\mathfrak{£ 5}$ deposit already paid. ${ }^{67}$

Presumably flattered to be the offered the chance to buy a brand new Chevrolet, it appears that Obisesan decided to solve the problem of not being able to afford Mr. Barnes's car by buying another one costing slightly more. He makes no comment on the financial absurdity of his plan; instead, the key concern is his reputation with the 'kind-hearted gentle Englishman'. He sacrifices the notinsignificant sum of $£ 5$ for breaking their agreement, although it is likely this would have been forfeited anyway. Nothing more is heard of Mr. Barnes; it appears that he did not write to 'Dear Mr. Obisesan' again. 
On 21 April, Obisesan describes a rather sour encounter with his boss, after arriving late at work. 'Vain Knox used disparaging language when remonstrating with me', he complained. The scene worsened in the afternoon, 'when he [Knox] was badly drunk \& began to complain about untidy condition of the shop'. This time, rather than adopting an obsequious attitude towards 'a white', Obisesan asserted himself and then reenacted the exchange in his diary: 'I made it plainly known to him that politeness was the order of the day \& if he would not be polite he stood the chance of losing his respect'. ${ }^{68}$ Notwithstanding that he owed Knox a vast sum of money, Obisesan assumed here a position of superiority, warning his boss that if his rude antics continued, he would lose 'his respect'. Importantly, Obisesan did not say 'my respect' because the issue, as he saw it, was not his own respect for Knox, but rather Knox's respect for himself. As someone who took his self-respect very seriously, the distinction was important. Furthermore, unlike entries where Obisesan projected an audience of himself, in this case, Obisesan projected the audience as himself. From this position, he could take the stage as the protagonist of politeness. 'The vain, drunkard Knox changed today for good', he wrote on 22 April. $^{69}$

Obisesan took possession of his car few weeks later, after paying $£ 100$ to Mr. Knox. 'I call this a great success', he wrote, '\& really it is' ${ }^{70}$ He could not be registered as the official owner because of his outstanding debt, but when another agent replaced Mr. Knox in July, Obisesan took advantage. 'The much discussed Chevrolet car became mine today', he wrote on 4 July, 'the new agent unconsciously agreed to my taking it'. ${ }^{71}$ The next day, however, he had to remonstrate with himself:

I am not in a happy mood of spirits, the cause is traceable to embarrassing condition financially; Fancy, a man who consciously admits having over $£ 300$ liability to pay again pushes himself in to another debt of $£ 200$. Many things I do is not done with deliberate intention to trick \& and to join gang of I don't care people: it is therefore to be said that they are done by the decision of the fate. ${ }^{72}$

In this entry, Obisesan projects in a 'gang of I don't care people' to assess the degree of his responsibility for his financial predicament. Although he acknowledges that the situation is at least partly self-inflicted, he again resorts to a fatalistic explanation that justifies his feeling of having limited control over his life.

But this narrative of fatalism involved a level of self-denial that took a psychological toll. Later in the week, Obisesan was practically suicidal:

The state of my mind today being like that of a man condemned not to be hanged at once \& finish with but to be tortured to death: it is evident that my day of disgrace, dishonour \& perhaps complete humiliation is imminent. ${ }^{73}$

Seemingly a glutton for self-torture, Obisesan later re-read this entry, using a blue pen to cross out 'all' and write in 'with'. Importantly, Obisesan referred here to 'social death'; he saw public self-abnegation as the only possible 
outcome if his white British bosses found about out the deficit he had run up in his shop. He had accumulated this debt partly as a result of pilfering to sustain his expensive lifestyle, but also because of the fluctuating price of produce and the continual failure of his customers to pay for goods they purchased on credit. Another factor was an economic climate increasingly prejudiced against small-scale local entrepreneurs; Obisesan was by no means the only African trader to struggle to make ends meet.

Despite his worst fears, Obisesan continued trading for another three years. However, his financial misdemeanours finally caught up with him on 4 September 1930, when Mr. Graham, the latest British agent for the UAC, shut down his shop after a stocktaking exercise. 'Proper disgrace thus has now come', Obisesan wrote, ' \& from tomorrow the news of my closing down will flash around every corner of Ibadan city \& travel also to distant places'. ${ }^{74}$ Even on this most humiliating of days, Obisesan still liked to think he had an audience. Three months later, he received a court summons to pay the princely sum of $£ 844.14$ still owing on his UAC account. ${ }^{75}$

\section{Conclusion}

By 1939, Obisesan's life situation had turned around following his success with setting up cooperatives for marketing cocoa. He was nominated and elected as a Councillor to the Ibadan Council, a role he took up with enthusiasm. All the same, he still watched with interest to see how others received and responded to him. He was gratified when, on $8 \mathrm{July}$, a group of prominent gentlemen in Ibadan celebrated his election with 'a function in my honour' ${ }^{76} \mathrm{~A}$ few weeks later, he noticed a report on the event in a prominent national newspaper. 'By this readers of Nigerian Daily Times everywhere will know my poor achievements in life', he concluded. ${ }^{77}$

That Obisesan could claim an audience of 'readers of Nigerian Daily Times everywhere' shows he had indeed come a long way from the dark days of 1927 and 1930. In fact, he had accumulated several layers of audience in this particular instance - his gentlemen friends, the journalist from the Nigerian Daily Times, readers (everywhere) of the newspaper, the 'future reader' of his diary, and of course himself. It was not sufficient for Obisesan to just read a newspaper story about himself. He had to write about it in his diary as well, because only then did it become real. Reading and writing about himself, he could enjoy the full effect of reflecting back to himself a pleasing image of self-hood. On 21 July 1939, he wrote up his diary entry as he always did and projected in his audience; that day he chose to re-constitute himself as falsely modest.

It appears that Obisesan was a person who could only exist in the gaze of others. Rather than being a transcript of individual consciousness, his diary is a document of the relational nature of personhood that simultaneously affirms and consolidates personal autonomy, agency and distinctiveness 
through the making of social relationships. Partly because his personhood was so actively made in relation to other people, Obisesan seems to have written his diary with audiences in mind. This audience was first and foremost himself. But, as we have seen, Obisesan's identity as the reader of his diary existed in dynamic relation to the many audiences he projected into the text. Across time, these multiple audiences helped Obisesan to cope with the feelings of isolation and helplessness that he sometimes experienced as he struggled to establish himself as a man of standing in colonial Ibadan. For most of his life during the 1920s, Obisesan eked out an existence on the fringes of colonial society. In this context of uncertainty, his multiple audiences consolidated his personhood and legitimated his precarious social position.

\section{Notes}

1. Bunkers and Huff, Inscribing the Daily, 1.

2. For example, Nkrumah, Autobiography of Kwame Nkrumah, Kenyatta, Facing Mount Kenya; and Azikiwe, My Odyssey: An Autobiography.

3. Hyslop, 'On Biography', 104. Hyslop refers specifically to South Africa, but his comments could be applied to Africa more generally.

4. Comaroff and Willan, Mafeking Diary.

5. 'Honourable Chief Akinpelu Obisesan Short History', 1. This typed biography was kindly given to me by Alhaji A.O. Obisesan of Ile Aperin. The account obscures Obisesan's mother's slave origins. The source for this is an interview I conducted with Akinpelu's son, the late Chief Lapade Obisesan, on 3 May 1997. He asserted that his grandmother was a slave captured in Ilesha.

6. 'The Hon'ble Akinpelu Obisesan' The Yoruba News, 4 May 1942, 2.

7. Watson, "What is Our Intelligence", 59.

8. Akinpelu Obisesan Papers (hereafter, OP), Kenneth Dike Library, University of Ibadan: Box N: 1914 Diary, 11-30 May entries.

9. OP Box N: 1914 Diary. The family tree is set out through the entries for 13 Feb.-11 April; births and deaths are reported throughout the diary book, but for example see 25-28 Jan. entries (births) and 13-15 April entries (deaths); accounts of dreams are also ubiquitous but see especially 25-27 May entries; there is an extended account of a vision in the entry for 19 Oct.

10. 'Honourable Chief Akinpelu Obisesan Short History'.

11. OP Box 55: 1920 Diary, entries for 12 and 20 Feb.

12. Gusdorf, 'Conditions and Limits of Autobiography', 29.

13. Bunkers and Huff, Inscribing the Daily, 4.

14. Rudolph and Rudolph, 'Becoming a Diarist', 115. See also their book, Reversing the Gaze, which publishes edited extracts of Amar Singh's diary.

15. Rudolph and Rudolph, 'Becoming a Diarist', 114.

16. Ibid., 115.

17. Ibid.

18. Ibid., 114.

19. Iser, 'Interaction between Text and Reader', 20.

20. Rudolph and Rudolph, 'Becoming a Diarist', 114.

21. Barber, Anthropology of Texts, 103. 
22. Ibid., 104.

23. Ibid., 109.

24. Brown, “Life Histories"', 588.

25. Vaughan and Kirk-Greene, Diary of Hamman Yaji, 19.

26. Barber, Anthropology of Texts, 186.

27. Ibid., 187.

28. Peterson, 'Casting Characters', 176.

29. Barber, Anthropology of Texts, 104.

30. Ibid., 103.

31. Ibid., 107.

32. Huff, 'Reading as Re-vision', 508.

33. Bunkers and Huff, Inscribing the Daily, 11.

34. OP Box 55: 1920 Diary, entries for 2 and 30 June; 1921 Diary, 27 July; Box 47: 1927 Diary, 24 Feb. In the 1921 entry Obisesan uses the phrase sarcastically, going on to recount how 'the fate of the family is on the horizon'.

35. OP Box 49: 1939 Diary, 10 April.

36. OP Box 49: 1939 Diary, 12 April.

37. OP Box 49: 1939 Diary, 14 April.

38. OP Box 49: 1939 Diary, 15 April.

39. OP Box 49: 1939 Diary, 16 April.

40. Adeboye, 'Reading the Diary', 78.

41. Watson, "What is Our Intelligence", 70.

42. OP Box 55: 1920 Diary, 24 Nov.

43. Watson, "What is Our Intelligence", 52-77.

44. Barber, 'Introduction', 3-7.

45. Chief Lapade Obisesan interview, 3 May 1997.

46. Adeboye, 'Reading the Diary', 78.

47. Chief Lapade Obisesan interview, 3 May 1997.

48. Barber, Anthropology of Texts, 176.

49. Ibid., 177.

50. Ibid., 186.

51. Chief Lapade Obisesan interview, 3 May 1997.

52. Miescher, "My Own Life", 44.

53. Ibid., 27.

54. Barber, 'Introduction', 2.

55. Barber, Anthropology of Texts, 187-8.

56. Adeboye, 'Reading the Diary', 86.

57. Post and Jenkins, Price of Liberty.

58. OP Box 47: 1927 Diary, 26 Feb.

59. OP Box 47: 1927 Diary, 21 Feb.

60. OP Box 47: 1927 Diary, 18 Feb.

61. OP Box 47: 1927 Diary, 23 Feb.

62. OP Box 47: 1927 Diary, 28 Feb.

63. OP Box 47: 1927 Diary, 1 March.

64. OP Box 47: 1927 Diary, 9 March.

65. OP Box 47: 1927 Diary, 22 March.

66. OP Box 47: 1927 Diary, 5 April.

67. OP Box 47: 1927 Diary, 14 April.

68. OP Box 47: 1927 Diary, 21 April.

69. OP Box 47: 1927 Diary, 22 April 
70. OP Box 47: 1927 Diary, 7 May.

71. OP Box 47: 1927 Diary, 4 July.

72. OP Box 47: 1927 Diary, 5 July.

73. OP Box 47: 1927 Diary, 7 July

74. OP Box 47: 1930 Diary, 4 Sept.

75. OP Box 47: 1930 Diary, 1 Dec.

76. OP Box 49: 1939 Diary, 8 July.

77. OP Box 49: 1939 Diary, 21 July.

\section{Acknowledgements}

This article is based on an earlier paper presented at the 'Transcending Boundaries: Biographical Research in Colonial and Postcolonial African History' conference at the German Historical Institute London, in May 2010. My thanks to Silke Strickrodt and Achim von Oppen for organising the conference. I am also grateful to Wayne Dooling, Isabel Hofmeyr and Silke Strickrodt for their helpful comments and suggestions.

\section{Funding}

This work was supported by a Research Leave Award from the Arts and Humanities Research Council [grant number 113102], which is gratefully acknowledged.

\section{References}

Adeboye, Olufunke. "Reading the Diary of Akinpelu Obisesan in Colonial Africa." African Studies Review 51 (2008): 75-97.

Azikiwe, Nnamdi. My Odyssey: An Autobiography. London: Hurst, 1970.

Barber, Karin. "Introduction: Hidden Innovators in Africa." In Africa's Hidden Histories: Everyday Literacy and Making the Self, edited by Karin Barber, 1-24. Bloomington: Indiana University Press, 2006.

Barber, Karin. The Anthropology of Texts, Persons and Publics: Oral and Written Culture in Africa and Beyond. Cambridge: Cambridge University Press, 2007.

Brown, Judith. "“Life Histories" and the History of Modern South Asia." The American Historical Review 114 (2009): 587-595.

Bunkers, Suzanne L., and Cynthia A. Huff. eds. Inscribing the Daily: Critical Essays on Women's Diaries. Amherst, MA: University of Massachusetts Press, 1996.

Comaroff, John, and Brian Willan, eds. The Mafeking Diary of Sol T. Plaatje. Cape Town: David Philip, 1999.

Gusdorf, Georges. "Conditions and Limits of Autobiography." In Autobiography: essays theoretical and critical, edited by James Olney, 28-48. Princeton: Princeton University Press, 1980.

Huff, Cynthia A. "Reading as Re-vision: Approaches to Reading Manuscript Diaries." Biography 23 (2000): 504-523.

Hyslop, Jonathan. "On Biography: A Response to Ciraj Rassool." South African Review of Sociology 41 (2010): 104-115.

Iser, Wolfgang. "Interaction between Text and Reader." In Readers and Reading, edited by Andrew Bennett, 20-31. Harlow: Longman, 1995.

Kenyatta, Jomo. Facing Mount Kenya. London: Secker and Warburg, 1938. 
Miescher, Stephan F. ““My Own life”: A.K. Boakye Yiadom’s Autobiography - The Writing and Subjectivity of a Ghananian Teacher-Catechist." In Africa's Hidden Histories: Everyday Literacy and Making the Self, edited by Karin Barber, 27-51. Bloomington: Indiana University Press, 2006.

Nkrumah, Kwame. The Autobiography of Kwame Nkrumah. Edinburgh: T. Nelson, 1957.

Peterson, Derek. "Casting Characters: Autobiography and Political Imagination in Central Kenya." Research in African Literatures 37 (2006): 176-192.

Rudolph, Susanne Hoeber, and Lloyd I. Rudolph. "Becoming a Diarist: Amar Singh's Construction of an Indian Personal Document." The Indian Economic and Social History Review 25 (1988): 113-132.

Rudolph, Susanne Hoeber, and Lloyd I. Rudolph, eds. Reversing the Gaze: Amar Singh's Diary, a Colonial Subject's Narrative of Imperial India. Boulder, CO: Westview Press, 2002.

Post, Kenneth W. J., and George D. Jenkins. The Price of Liberty: Personality and Politics in Colonial Nigeria. Cambridge: Cambridge University Press, 1973.

Vaughan, James H., and Anthony H. M. Kirk-Greene, eds. The Diary of Hamman Yaji: Chronicle of a West African Muslim Ruler. Bloomington: Indiana University Press, 1995.

Watson, Ruth. "“What is Our Intelligence, Our School Going and Our Reading of Books without Getting Money?" Akinpelu Obisesan and His Diary.” In Africa's Hidden Histories: Everyday Literacy and Making the Self, edited by Karin Barber, 52-77. Bloomington: Indiana University Press, 2006. 